\title{
Urban Local Air Quality Management Framework for Non- Attainment Areas in Indian Cities
}

\author{
Sunil Gulia ${ }^{1}$, S. M. Shiva Nagendra ${ }^{2}$, Jo Barnes ${ }^{3}$, Mukesh Khare K* $^{4 *}$ \\ ${ }^{1}$ Former Senior Project Scientist, Civil Engineering Department, Indian Institute of Technology \\ Delhi, Hauz Khas, New Delhi, India (sunilevs@gmail.com) \\ ${ }^{2}$ Associate Professor, Civil Engineering Department, Indian Institute of Technology Madras, \\ Chennai, India (shivanagendra@yahoo.com) \\ ${ }^{3}$ Senior Research Fellow, AQMRC, University of West of England, UK (Jo.Barnes@uwe.ac.uk) \\ ${ }^{4}$ Professor, Civil Engineering Department, Indian Institute of Technology Delhi, Hauz Khas, \\ New Delhi, India \\ *Corresponding Author: \\ Address: Room No.220, Civil Engineering Department, Block -IV, Indian Institute of \\ Technology Delhi, Hauz Khas, New Delhi-110016, India \\ E-mail address: kharemukesh@yahoo.co.in \\ Tel.: +91-11-26591212; Fax: +91-11- 26581117.
}

\section{Abstract}

Increasing urban air pollution level in Indian cities is one of the major concerns for policy makers due to its impact on public health. The growth in population and increase in associated motorised road transport demand is one of the major causes of increasing air pollution in most urban areas along with other sources e.g., road dust, construction dust, biomass burning etc. The present study documents the development of an urban local air quality management (ULAQM) framework at urban hotspots (non-attainment area) and a pathway for the flow of information from goal setting to policy making. The ULAQM also includes assessment and management of air pollution episodic conditions at these hotspots, which currently available city/ regional-scale air quality management plans do not address. The prediction of extreme pollutant concentrations using a hybrid model differentiates the ULAQM from other existing air quality management plans. The developed ULAQM framework has been applied and validated at one of the busiest traffic intersections in Delhi and Chennai cities. Various scenarios have been tested targeting the effective reductions in elevated levels of $\mathrm{NO}_{\mathrm{x}}$ and $\mathrm{PM}_{2.5}$ concentrations. The results indicate that a developed ULAQM framework is capable of providing an evidence-based graded action to reduce ambient pollution levels within the specified standard level at pre-identified locations. The ULAQM framework methodology is generalised and therefore can be applied to other non-attainment areas of the country.

Keywords: Urban local air quality management framework, non-attainment area, vehicular pollution, episodic condition, hybrid model. 


\section{Introduction}

Urban air pollution (UAP) is a major concern in most megacities (with population > 10 million) around the world. The pollution level exceeds the national and international ambient as well as health- based air quality standards (Gurjar et al., 2008; Marlier et al., 2016). The growth in urban population and associated increased volume of motorised traffic in cities are majorly responsible for severe air pollution (MoPNG, 2003; Badami, 2005; Molina et al., 2007; Singh et al., 2007; Wang et al., 2010; Kumar et al., 2017). The sudden rise in vehicle exhaust emissions during peak traffic period results into extreme air pollution events (episodes) at urban hotspots (Chelani, 2013; Pant et al., 2015; Cakmak et al., 2016). Urban hotspot is the location in the city where air pollution level are already fails or likely to fails to meet national ambient air quality standards (NAAQS) due to high source activities or adverse meteorological condition or both. Mostly, the central business districts, busy traffic intersections and heavy trafficked congested roadways convert in to urban hotspot (Gokhale and Khare, 2007; Kanlindkar, 2007; Tiwari et al., 2012). Due to the heterogeneous and unplanned growth of cities in developing countries, the movement of vehicles is non-uniform throughout the city, which results in high spatial variations in pollutant emissions leading to formation of urban hotspots. In addition, topographical and meteorological variations in urban areas lead to complex spatial and temporal variations in pollutant concentrations (Gokhale and Khare, 2007).

Over the last few years, increasing air pollution in the mega and growing cities in India has become one of the major problems affecting the environment (Gurjar et al., 2016; Amann et al., 2017). Air pollution concentrations frequently exceed NAAQS especially during the winter season when atmospheric dispersion potential is very low (Guttikunda et al. 2014; Gulia et al., 2017a). In particular for Delhi city, increasing concentrations of particulate matter (PM) result in tens of thousands of premature deaths and six million asthma attacks each year (Guttikunda and Goel, 2013; Lelieveld et al., 2015). Kesavachandran et al. (2015) have reported that those undertaking physical exercise outdoors at locations with higher $\mathrm{PM}_{2.5}(\leq 2.5 \mu \mathrm{m}$ in aerodynamic diameter) concentrations in Delhi are at a risk of lung function impairment. Further, Maji et al. (2016) have estimated that mortality attributable to $\mathrm{PM}_{10}$ in Mumbai and Delhi has increased by $\sim 1.6$ and $\sim 2.5$ times, respectively in year 2015 compared to year 1995. However, annual average mortality due to $\mathrm{PM}_{2.5}$ in Mumbai and Delhi was reported 10,880 and 10,900, respectively in the year 2015. They also estimated that total economic cost increased from US\$2680.87 million to US\$ 4269.60 million for Mumbai city and US\$2714.10 million to US\$ 6394.74 million for Delhi city from year 1995 to year 2015 due to increased PM$_{10}$ concentrations. Therefore, there is a need to reduce air pollution exposure related health impacts which can be accomplished by controlling/managing the increasing urban air pollution loads through an efficient and effective integrated management plan.

Current air quality management practices/action plans (AQMP) (CPCB, 2006; NILU, 2007; Sivertsen, 2008; Moussiopoulos et al., 2010) are useful at the city level but inadequate to address sudden rises in pollution at an urban hotspot or non-attainment area (NAA). Each NAA is unique in terms of spatial and temporal patterns of emission sources. Therefore, one of the essential requirements is the site specificity of an AQMP, which make it capable of effectively dealing with the complexity of atmospheric changes, topographical constraints and pollution sources at local scale. The concept of air quality management at a local level, as required by the Environment Act 1995 in the United Kingdom (UK), is described by Longhurst et al. (1996) for notified air quality management areas. The researchers emphasise the importance of the role of relevant local 
government departments, for air quality management at a local scale. Later, Beattie et al. (2002) have reviewed the working pattern of various local authorities in England and found gaps in joint working between departments within the authorities and with non- local government agencies impacted on the successful implementation of the local air quality management process. They also observed a lack of political will and funding for implementation of mitigation measures for air quality improvement. As a result, they suggested that effectiveness of particular measures should be evaluated not only based on scientific and economic parameters but also on public and political acceptability. In the UK, local air quality is still managed through an improved version of the Local Air Quality Management (LAQM) framework (DEFRA, 2016). Following the UK LAQM approach, Gokhale and Khare (2007) have also introduced the concept of an episodic urban air quality management framework to control CO pollution for Delhi city. However, this is currently a theoretical framework and not tested to evaluate the impacts of interventions. Recently, Li et al., 2017 suggested that air quality management strategies, including regional environmental coordination and collaboration, restrictive vehicle emission standards and promotion of public transport should strictly implement for improvement of urban air quality. They also reported that source apportionment based on high time resolution of trace element can be a powerful tool for local air quality management.

The present study aims to formulate an urban local air quality management (ULAQM) framework to manage the exceedences of air pollution thresholds at specified locations in urban areas in Indian cities. Further, the developed framework has been tested theoretically to investigate its effectiveness in reducing $\mathrm{NO}_{\mathrm{x}}$ and $\mathrm{PM}_{2.5}$ concentrations in Delhi and Chennai cities, respectively.

\section{Status of vehicular air pollution in India}

Motorised vehicles have emerged as one of the major contributors to increased levels of urban air pollution in India (Sharma \& Dikshit, 2016; Kumar et al., 2017; Dhyani et al., 2017). The population of registered vehicles in India has increased from 67 million in 2003 to 210 million in 2015 (MoRTH, 2017). Similar growth has been observed in fuel consumption. Based on 2012-13 data, India's total diesel and petrol consumptions were 69.74 and 15.7 million tons, respectively with the transport sector accounting for about $70 \%$ of diesel and $99.6 \%$ of petrol consumption (MoPNG, 2013). In Indian metropolitan cities (Delhi, Mumbai, Kolkata, and Chennai), ambient PM concentrations frequently violate the NAAQS as well as WHO guideline thresholds (Gupta and Kumar, 2006; Singh et al., 2007; CPCB, 2010; Gupta et al., 2010). Ramachandra and Shwetmala (2009) have reported that India's transport sector emits $258.10 \mathrm{Tg}$ of $\mathrm{CO}_{2}$, of which 94.5\% is due to motorised road transport. The Central Pollution Control Board (CPCB) Delhi has reported that vehicular emission contribution to the total urban air pollution in Delhi and Mumbai is about 76-90\% for $\mathrm{CO}, 66-74 \%$ for $\mathrm{NO}_{x}, 5-12 \%$ for $\mathrm{SO}_{2}$ and 3-12\% for PM (CPCB, 2010a). In the recent past, Sharma and Dixit (2016) have estimated that approximately 12.9 Ton/day, 11.6 Ton/day, 113.4 Ton/day, 1.2 Ton/day and 322.4 Ton/day of $\mathrm{PM}_{10}, \mathrm{PM}_{2.5}, \mathrm{NO}_{\mathrm{x}}, \mathrm{SO}_{2}$ and $\mathrm{CO}$, respectively are emitted from in use road vehicles in Delhi city. This indicates that urban air quality in developing countries is deteriorating due to high vehicular activities and related inadequate management practices. The following sub-sections discuss the sources and other related air pollution issues in two Indian megacities, Delhi and Chennai cities (Sections $2.1 \& 2.2$ ) which have also been considered as case study examples in the application of the developed ULAQM. 


\subsection{Delhi city}

Delhi city has a population of 16.8 million, which has grown at a decadal growth rate of $47 \%$ (Census, 2011) spread over an area of $1483 \mathrm{~km}^{2}$ at average altitude of $\sim 215 \mathrm{~m}$ above mean sea level. The city faces heavy seasonal climatic variability. For example, temperature varies from minimum of $4-5{ }^{\circ} \mathrm{C}$ during the winter (months of December - February) to maximum of $45-48{ }^{0} \mathrm{C}$ during the summer (months of March- May) (Perrino et al., 2011). The winter season faces frequent ground based inversion conditions which restrict the dispersion of pollutants. Further, the monsoon season experiences more than $80 \%$ of the annual rainfall. Studies consistently show high $\mathrm{PM}_{10}$ and $\mathrm{PM}_{2.5}$ concentrations in the ambient air of Delhi, irrespective of location type (Mandal et al., 2014; Pant et al., 2015; Sharma et al., 2013a; Tiwari et al., 2014). In the recent past, studies have ranked Delhi as the "worst" polluted city based on an environment performance index (Hsu and Zomer, 2014). The current road length in Delhi city is 33,198 km with 864 signalized and 418 blinker traffic intersections. The road network has increased from $28,508 \mathrm{~km}$ in 2000 to $33,198 \mathrm{~km}$ in 2015; while the number of vehicles has more than doubled from 3.37 million in 2000 to 8.83 million in 2015 (GoD, 2016; NCR, 2013). However, vehicles population of 2.0 million in Mumbai and 3.7 million in Chennai were reported in year 2015 (Gupta, 2015). This increase has resulted in heavy traffic congestion and a reduction in vehicular speed on the roads leading to increased emissions of pollutants, such as, $\mathrm{PM}_{2.5}, \mathrm{PM}_{10}(\leq 10 \mu \mathrm{m})$ and $\mathrm{NO}_{\mathrm{x}}$ (oxides of nitrogen) (CPCB, 2010a; Dhyani et al., 2017). Mohan and Kandya (2007) have analysed nine year's (1996-2004) data at seven different locations in Delhi city and created an Air Quality Index (AQI). They have reported that annual average $\mathrm{NO}_{2}$ concentrations have been found in the range of 50-90 $\mu \mathrm{g} \mathrm{m}^{-3}$ during 1996 to 2004 at one ITO intersection. A summary of past studies between 1997 and 2016 is presented as supplementary information (SI) in Table S1, which indicates the concentrations of PM and gaseous pollutants in ambient air exceeded the NAAQS.

\subsection{Chennai City}

Chennai is one of the seventeen declared NAAs in India notified by CPCB. It has a population of 7.08 million (Census, 2011) over a geographical area of $426 \mathrm{~km}^{2}$. The city is located on the Southeast coast of India at an average altitude of six metres above mean sea level. The city has four major seasons, namely, summer (April-June) and pre-monsoon (July-September) and monsoon (October-December) and winter (January- March). In summer, the city experiences humid weather and strong wind with the mean daily temperature reaching $36 \pm 2{ }^{\circ} \mathrm{C}$. It is characterised by land and sea breezes and frequent cyclonic storms. During winter, the ambient temperature reaches $21 \pm 2^{\circ} \mathrm{C}$. The monsoon generates $90 \%$ of annual rainfall (Jayanthi and Krishnamoorthy, 2006). The vehicles population in Chennai city was reported around 3.7 million in year 2015 with highest vehicle density of 2093 per km road length when compared to other Indian cities (Gupta, 2015). Sivaramasundaram and Muthusubramanian (2010); Srimuruganandam and Nagendra, (2011) have found that PM levels exceed the NAAQS at selected urban locations in Chennai city where vehicular movement were found highest. Further, it is observed that diesel exhausts (43-52\% in $\mathrm{PM}_{10}$ and 44-65\% in $\mathrm{PM}_{2.5}$ ) and gasoline exhausts (6-16\% in $\mathrm{PM}_{10}$ and 3$8 \%$ in $\mathrm{PM}_{2.5}$ ) are found to be the major source contributors at one of the kerb site in Chennai city (Srimuruganandam and Nagendra, 2012). Madala et al. (2016) have simulated the $\mathrm{NO}_{\mathrm{x}}$ level at seven different location in Chennai city using a lagrangian particle dispersion model (LPDM) 
considering all point, area and line sources and found high seasonal variation in $\mathrm{NO}_{\mathrm{x}}$ concentration at all locations.

\subsection{Urban air quality management in India}

Policy makers in India started taking an interest in air pollution control policies after the Stockholm Conference on the Human Environment in year 1972 and identified that the nation was in need of environmental legislation to control air pollution. As a result, the Air (Prevention and Control of Pollution) Act 1981 came into force with the goal of prevention, control, and abatement of air pollution. It is a very comprehensive legislation and empowers Central and State Pollution Control Boards (SPCBs) to declare pollution control areas, to put restrictions on certain industrial units to limit their emissions of air pollutants and to enter, inspect and carrying out monitoring. In addition, CPCB provides technical assistance and guidance to the SPCBs and carry out and sponsor investigations and research related to air pollution. The first ambient air quality standards for three criteria pollutant $\left(\mathrm{SO}_{2}, \mathrm{NO}_{2}\right.$ and SPM) separately for industrial, residential and sensitive areas were adopted in year 1982 by the CPCB under this Act. The NAAQS were later revised in 1994 with the addition of three more pollutants for daily and annual averages (except $\mathrm{CO}$ which is 8hour average). The latest NAAQS were again revised in year 2009 for a total of 12 pollutants.

The national air monitoring program (NAMP) started in 1984 with seven stations in Agra and Anpara. However, at present, total 591 ambient air quality monitoring stations are operated in 248 cities/towns in 28 states and four union territories, and the network is expanding rapidly with the inclusion of further continuous real time monitors (CPCB, 2015). Additionally, individual SPCBs operate their own monitoring stations. In recent years, the Ministry of Earth Sciences, Government of India (GoI) has started monitoring and forecasting air quality in four cities (Delhi, Mumbai, Pune and Ahmedabad) under the SAFAR program (IITM, 2017).

Emission reduction from vehicle's exhaust in India commenced from year 1990 with notification of mass emission norms at the manufacturing stage for new vehicles. The CPCB along with concerned SPCB has prepared city scale action plans for the selected seventeen cities to reduce urban air pollution following orders of Honorable Supreme Court of India of year 2001 (CPCB, 2006). Various control strategies have been introduced in the last few years (CPCB, 2010b). In the recent past, government/ regulatory agencies have taken various measures to curb emissions from motor vehicles (Gulia et al., 2015). Various recommendations from Auto Fuel Policy (MoPNG, 2003) have been adopted for reduction of vehicular pollution through enhancing better engine technology, fuel quality and reducing related emissions, alternative fuels, the introduction of Bharat Stage (BS) Norms (equivalent to EURO standards), restriction/ban on diesel/petrol vehicles older than 10 and 15 years, respectively; mandatory use of clean fuel (CNG/LNG) in commercial and public transport; restrictions on movements of heavy vehicles in the city during daytime; declaration of low emission zones; road space rationing etc. Recently, GoI has decided to leapfrog to BS VI norms in 2020 from BS IV with an amendment in Central Motor Vehicles Rule, 1989 (MoRTH, 2016). In year 2015, due to deteriorating air quality in Delhi, emergency measures were undertaken. The Honourable Supreme Court of India banned the registration of $\geq 2000 \mathrm{cc}$ diesel vehicles in Delhi which was revoked with an additional $1 \%$ environmental levy on the purchase of such vehicles. In another such emergency measure to improve air quality in Delhi, rationing of private cars was carried out on the basis of the registration number of vehicles i.e. vehicles with odd registration permitted on odd date and vehicle with an even registered number permitted on 
even date (Kumar et al., 2017). Recently, the Ministry of Environment, Forest and Climate Change has notified a Graded Response Action Plan (GRAP) to tackle air pollution episodes in Delhi NCR region in January 2017 (MoEF\&CC, 2017). However, the efficacy/potential of this GRAP in reducing the ambient pollution levels still needs to be assessed scientifically. In addition, establishment of a National Green Tribunal (NGT) at the National Level and creation of an Environmental Pollution Control Authority (EPCA) in Delhi-NCR, are some important steps taken by the Indian government in order to manage increasing ambient air pollution. In spite of the above actions, the air pollution in Indian cities like Delhi is still exceeding the specified standards.

\subsection{Urban air quality management related to vehicular emission in developed countries}

Urban air quality in cities of developed countries is showing signs of improvement, apparently due to implementation of the urban air pollution management plans. In Europe, the emission reduction from vehicular exhausts from year 1990 to year 2009 has been reported to be around $54 \%$ for $\mathrm{SO}_{2}$, $27 \%$ for $\mathrm{NO}_{\mathrm{X}}, 16 \%$ for $\mathrm{PM}_{10}$ and $21 \%$ for $\mathrm{PM}_{2.5}$ (EEA, 2011). In North American megacities like Los Angeles, New York, and Mexico City, the pollutant concentrations for some criteria pollutants have shown declining trends, particularly in tropospheric ozone $\left(\mathrm{O}_{3}\right)$. However, at some designated non-attainment areas, national ambient air quality standards are still exceeded (Parrish et al., 2011). In New South Wales (NSW) in Australia, one-hourly average $\mathrm{NO}_{2}$ concentrations have shown a declining trend from 1980 to 2009, which may be due to the implementation of cleaner fuel standards (NSW Government, 2010).

In the UK, urban air quality management strategies are implemented and regularly monitored at specially designated Air Quality Management Areas (AQMAs) (DEFRA, 2016). Some successful urban air quality management programmes which appear to have reduced pollution levels are described in Table 1.

Table 1: Urban air quality management programmes in different cities/countries

\begin{tabular}{|c|c|c|c|}
\hline City/ Country & $\begin{array}{l}\text { Management } \\
\text { Practices }\end{array}$ & Impact on Air Quality & Reference \\
\hline London/England & $\begin{array}{l}\text { Congestion and } \\
\text { road user } \\
\text { charging }\end{array}$ & $\begin{array}{l}\text { Significantly reduced } \mathrm{CO}_{2}, \mathrm{NO}_{\mathrm{x}} \text { and } \\
\mathrm{PM}_{10} \text { concentrations by } 16.4 \% \text {, } \\
13.4 \% \text {, and } 6.9 \% \text {, respectively which } \\
\text { further improve health benefit }\end{array}$ & EEA, 2008 \\
\hline USA & $\begin{array}{l}\text { Vehicular } \\
\text { exhaust emission } \\
\text { control }\end{array}$ & $\begin{array}{l}\mathrm{PM}_{2.5} \text { emissions has reduced by } 24 \% \\
\text { and } 21 \% \text { in Los Angeles and } \\
\text { Rubidoux, respectively from year } \\
2002 \text { to year } 2012\end{array}$ & $\begin{array}{l}\text { Hasheminassab } \\
\text { et al., } 2014\end{array}$ \\
\hline USA & $\begin{array}{l}\text { State } \\
\text { Implementation } \\
\text { Plan (SIP) }\end{array}$ & $\begin{array}{l}\text { Efficient and effective SIP in a region } \\
\text { of Connecticut, Georgia, Illinois, } \\
\text { Indiana, Kentucky, Maryland, }\end{array}$ & $\begin{array}{l}\text { Cohan and } \\
\text { Chen, } 2014\end{array}$ \\
\hline
\end{tabular}


Michigan, Missouri, New Jersey,

New York, North Carolina, Ohio,

Pennsylvania, Tennessee and West

Virginia and the District of Columbia

has helped in achieving the goal of

bringing down the concentrations of

$\mathrm{PM}_{2.5}$ within the prescribed standards

\begin{tabular}{llll}
\hline Barcelona, Spain & $\begin{array}{l}\text { Improvement in } \\
\text { Traffic Fleet }\end{array}$ & $\begin{array}{l}\text { Significantly reduced ambient } \\
\text { concentrations of } \mathrm{NO}_{2} \text { and } \mathrm{PM}_{10} \\
\text { concentration }\end{array}$ & $\begin{array}{l}\text { Soret et al., } \\
2013\end{array}$ \\
\hline Mexico City & $\begin{array}{l}\text { Low-emitting } \\
\text { vehicles and Bus } \\
\text { Rapid Transit }\end{array}$ & $\begin{array}{l}\text { Significantly reduced urban air } \\
\text { pollution levels }\end{array}$ & $\begin{array}{l}\text { Baeza and } \\
\text { Pardo, 2014 }\end{array}$ \\
\hline
\end{tabular}

The cited examples clearly show definite benefits of implemented management practices that have improved urban air quality. Further, an effective and efficient air quality management framework requires interconnectivity between its various components. In the UK, following LAQM regulatory guidelines, AQMAs are first identified based on areas exceeding the national air quality objectives. Air Quality Action Plans are then implemented to improve ambient air quality in the designated area. Looking at the increasing urbanization globally especially in developing countries, there is an urgent need to equip air quality regulatory authorities with an effective and efficient ULAQM framework. The framework must consist of interconnected components such as air quality standards/limits for all criteria and hazardous air pollutants; a continuous real-time air quality monitoring network along with screen display systems; an efficient comprehensive and updated emission inventory (e.g. online source emission inventory or e-inventory); air quality modelling (able to capture episodic conditions and also chemically reactive species) and control practices (based on their efficacy in reducing pollution level, socio-economic feasibility) and public participation (starting from goal setting to decision making).

\section{Development and formulation of ULAQM framework}

The urban air quality management practices are country specific, based on priorities agreed for a specific AQMAs to maintain acceptable ambient air quality, and are implemented and enforced through legislative laws (Longhurst et al., 1996). The key components of ULAQM are air quality objectives, monitoring, emission inventory, prediction and forecasting tools, control strategies and public participation. Further, each component plays a significant role in improving the efficiency of the ULAQM, thus reducing pollutant concentrations. The effective and efficient implementation of ULAQM in developing countries still remains a challenging task for air quality managers due to lack of government commitments and stakeholder participation, weaknesses in policies,

272 standards and regulations, lack of real-time air quality data and emission inventories (Naiker et al., 273 2012). The management practices to improve urban air quality are very limited, and the portion of 
274 the budget allocated for urban air quality management is insufficient especially in developing countries. Kura et al. (2013) have analysed urban air pollution problems in China, India and Brazil at a macro urban scale and proposed a system based methodology to develop the UAQM that takes into account: (i) identification of critical pollutants and their sources, (ii) setting up of the air

278 quality monitoring network, (iii) development of emission inventories, (iv) source prioritization,

279 (v) control strategies and (vi) development of decision support system. The comparative description of air quality management frameworks developed by researchers and/or adopted by governments to tackle increasing urban air pollution are presented in Table 2.

Table 2: Comparative review of selected air quality management frameworks

\begin{tabular}{|c|c|c|c|c|c|}
\hline \multirow[t]{2}{*}{ Parameters } & \multicolumn{5}{|c|}{ Air quality management framework } \\
\hline & LAQM & SIP & AQMS & AQMP & e-UAQMP \\
\hline Country & UK & USA & $\begin{array}{l}\text { Suggested } \\
\text { for } \\
\text { Developing } \\
\text { Countries* }\end{array}$ & South Africa & - \\
\hline $\begin{array}{l}\text { Identification of } \\
\text { Area }\end{array}$ & $\begin{array}{c}\text { AQMA } \\
\text { declaration } \\
\text { by local } \\
\text { authority }\end{array}$ & $\begin{array}{c}\text { AQCR } \\
\text { declaration } \\
\text { by central } \\
\text { agency }\end{array}$ & - & - & AQCR \\
\hline Goal Setting & $\begin{array}{c}\text { Long \& short } \\
\text { term } \\
\text { objectives }\end{array}$ & $\begin{array}{c}\text { Long } \\
\text { term/nationa } \\
1 \text { level }\end{array}$ & $\begin{array}{c}\text { Long } \\
\text { term/national } \\
\text { level }\end{array}$ & $\begin{array}{c}\text { Long } \\
\text { term/national } \\
\text { level }\end{array}$ & $\begin{array}{c}\text { Short term / } \\
\text { episodic/ } \\
\text { Area specific }\end{array}$ \\
\hline $\begin{array}{l}\text { Air quality } \\
\text { assessment }\end{array}$ & $\mathrm{X}$ & $\mathrm{X}$ & $\mathrm{X}$ & $\mathrm{X}$ & $\mathrm{X}$ \\
\hline $\begin{array}{l}\text { Source } \\
\text { apportionment }\end{array}$ & $X$ & - & - & - & - \\
\hline $\begin{array}{l}\text { Emission } \\
\text { inventory }\end{array}$ & $X$ & $X$ & $\mathrm{X}$ & $\mathrm{X}$ & $\mathrm{X}$ \\
\hline $\begin{array}{l}\text { Air Quality } \\
\text { Modelling }\end{array}$ & $\begin{array}{c}\text { (Screening or } \\
\text { detailed } \\
\text { dispersion } \\
\text { modelling) }\end{array}$ & $\begin{array}{c}\text { Gaussian } \\
\text { dispersion } \\
\text { model }\end{array}$ & $\begin{array}{c}\text { Gaussian } \\
\text { dispersion } \\
\text { model }\end{array}$ & $\begin{array}{c}\text { Gaussian } \\
\text { dispersion } \\
\text { model }\end{array}$ & $\begin{array}{c}\text { Hybrid } \\
\text { model } \\
\text { (Statistical } \\
\text { distribution - } \\
\text { Gaussian } \\
\text { dispersion } \\
\text { model) }\end{array}$ \\
\hline $\begin{array}{c}\text { Health Exposure } \\
\text { Assessment }\end{array}$ & - & - & $\mathrm{X}$ & - & - \\
\hline $\begin{array}{c}\text { Short term } \\
\text { control measure }\end{array}$ & - & - & - & - & $\begin{array}{c}\text { Alert/warnin } \\
\mathrm{g} / \\
\text { emergency }\end{array}$ \\
\hline $\begin{array}{l}\text { Long term } \\
\text { control } \\
\text { measures }\end{array}$ & $\mathrm{X}$ & $\mathrm{X}$ & $\mathrm{X}$ & $\mathrm{X}$ & $\mathrm{X}$ \\
\hline
\end{tabular}




\begin{tabular}{|c|c|c|c|c|c|}
\hline Evaluation & $\mathrm{X}$ & $\mathrm{X}$ & - & $\mathrm{X}$ & $\begin{array}{c}\mathrm{X} \\
\text { (Evaluation } \\
\& \text { re- } \\
\text { evaluation) }\end{array}$ \\
\hline $\begin{array}{c}\text { Public } \\
\text { Consultation/ } \\
\text { Participation }\end{array}$ & $\begin{array}{c}\text { X } \\
\text { (Consultation } \\
\text { from goal } \\
\text { setting to } \\
\text { implementati } \\
\text { on but Public } \\
\text { Participation } \\
\text { not essential ) }\end{array}$ & $\mathrm{X}$ & $\mathrm{X}$ & $\begin{array}{c}\mathrm{X} \\
\text { (Consultatio } \\
\mathrm{n} \text { in goal } \\
\text { setting and } \\
\text { baseline } \\
\text { setup) }\end{array}$ & - \\
\hline Policy Making & $\mathrm{X}$ & $\mathrm{X}$ & - & $\mathrm{X}$ & $\mathrm{X}$ \\
\hline Responsibility & $\begin{array}{c}\text { Local } \\
\text { authority } \\
\text { through } \\
\text { Policy and } \\
\text { Technical } \\
\text { Guidance } \\
\end{array}$ & $\begin{array}{c}\text { Local } \\
\text { authority }\end{array}$ & $\begin{array}{l}\text { National } \\
\text { agency }\end{array}$ & $\begin{array}{l}\text { National } \\
\text { agency }\end{array}$ & $\begin{array}{c}\text { Urban } \\
\text { development } \\
\text { authority }\end{array}$ \\
\hline $\begin{array}{l}\text { Time frame to } \\
\text { implement } \\
\text { actions }\end{array}$ & - & $\begin{array}{c}3 \text { year after } \\
\text { AQCR } \\
\text { declaration }\end{array}$ & - & - & - \\
\hline Reference & $\begin{array}{l}\text { Longhurst et } \\
\text { al. (1996); } \\
\text { DEFRA } \\
(2016)\end{array}$ & NRC (2004) & $\begin{array}{c}\text { Steinar et al. } \\
(1997)\end{array}$ & $\begin{array}{l}\text { DEAT } \\
(2008)\end{array}$ & $\begin{array}{l}\text { Gokhale and } \\
\text { Khare (2007) }\end{array}$ \\
\hline
\end{tabular}

'-' not part of framework; ' $\mathrm{X}$ ' part of framework

By analysing and understanding the strength and limitations of existing urban air quality management frameworks as described in Table 2, the present ULAQM framework has been formulated and tested theoretically to manage increasing air pollution at specified urban locations in Indian cities. The ULAQM framework incorporates almost all required functionality of an efficient and effective management plan enabling decision makers to deliberate upon the policies needed for managing the local air quality problems including episodic conditions. The ULAQM is different to other existing air quality management frameworks with the exception that it can also deal with extreme pollutant concentrations. Figure 1 shows the ULAQM framework with a description of its key components. The importance and functionality of each key components are described below followed by example case studies. The present ULAQM framework is targeted at controlling ambient $\mathrm{NO}_{\mathrm{x}}$ and $\mathrm{PM}_{2.5}$ concentrations at selected NAAs in Delhi and Chennai cities, respectively.

\subsection{Goals of the ULAQM framework}

The primary goal of the ULAQM framework is to attain or maintain 24-hour as well as hourly average $\mathrm{NO}_{\mathrm{x}}$ and $\mathrm{PM}_{2.5}$ concentrations within specified standards at selected NAAs. In India, NAAQS for $\mathrm{NO}_{\mathrm{x}}$ and $\mathrm{PM}_{2.5}$ are available only for annual and 24-hour average concentrations 
301 (Table 3). However, it is also important to assess hourly average concentrations of air pollutants 302 to effectively and efficiently manage short-term exceedences of these pollutants that are likely to 303 have an acute effect on human health. Therefore, WHO guidelines of $200 \mu \mathrm{g} / \mathrm{m}^{3}$ hourly average 304 have been used for analysing exceedences of $\mathrm{NO}_{\mathrm{x}}(\mathrm{WHO}, 2005)$ and, for $\mathrm{PM}_{2.5}$, the Canadian 305 standard, which is $80 \mu \mathrm{g} / \mathrm{m}^{3}$, has been used (Gulia et al., 2017a; Fu et al., 2000; DEQ Idaho, 2001).

Table 3: Ambient air quality standards/guidelines

\begin{tabular}{lccc}
\hline Pollutants & Annual average* & 24 hour average** & 1 hour average \\
\hline NO $_{\mathbf{x}}\left(\boldsymbol{\mu g} / \mathbf{m}^{\mathbf{3}}\right)$ & 60 & 80 & $200^{\#}$ \\
\hline $\mathbf{P M}_{2.5}\left(\boldsymbol{\mu g} / \mathbf{m}^{\mathbf{3}}\right)$ & 40 & 60 & $80^{\# \#}$
\end{tabular}

* Annual arithmetic mean of minimum 104 measurements in a year taken twice a week 24 hourly at uniform interval (MoEF\&CC, 2009)

** 24-hourly/8-hourly values should be met $98 \%$ of the time in a year. However, $2 \%$ of the time, it may exceed but not on two consecutive days.

\#WHO, (2005)

\#\# Fu et al. (2000); DEQ Idaho (2001) 


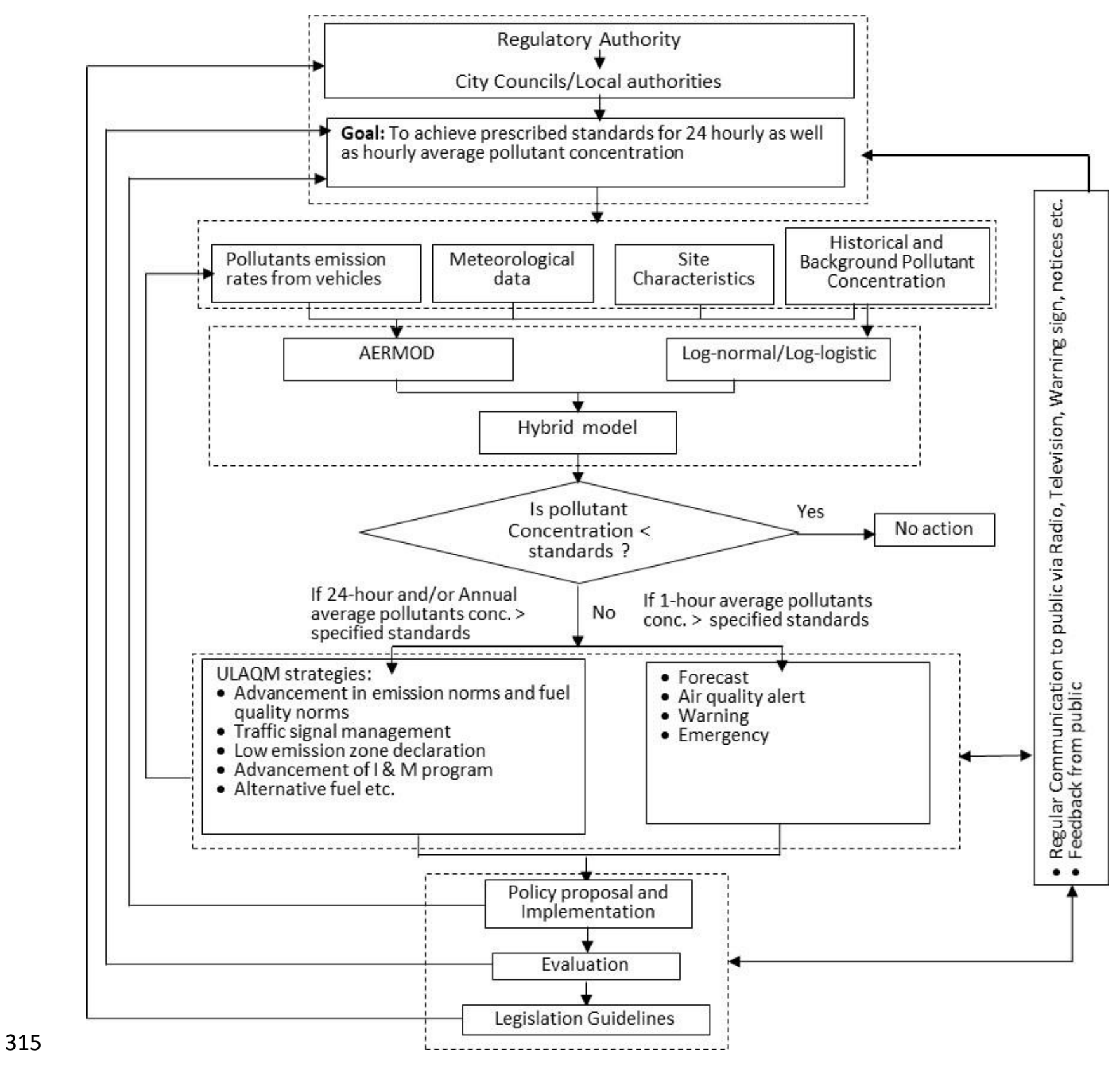

Figure 1: ULAQM framework

Ambient air quality monitoring is an important aspect of ULAQM which assesses the current air quality status as well as evaluates existing policies. Air quality monitoring is used to identify and declare the NAAs by comparing pollutant concentrations with standards. The protocol for ambient air quality monitoring including real time continuous monitoring, has already been developed by CPCB (2011). Real time continuous monitoring is essential to analyse the temporal variations of pollutant concentrations within the NAAs, especially during air pollution episodes. In addition, quality assurance/quality control protocols are also required including specifications for 
operation/maintenance of a monitoring network. The ULAQM framework also supports the use of a low-cost sensor based wireless air quality monitoring network for Indian cities. This kind of air quality monitoring network provides indicative high-resolution spatial data throughout the city at very low cost, which is one of the important concerns for policy makers in developing countries including India (Kumar et al., 2015b). High spatial resolution of air quality monitoring data is required because of the high spatial variation of emission sources and urban structures (unplanned and heterogeneous growth). This will strengthen the management plan in identifying the NAA areas and assist in evolving early hazard warnings to protect receptors from high ambient air pollution levels. However, their robustness in measuring pollutant concentration must be evaluated before their deployment. ULAQM also suggests capacity building of city councils/local authorities to measure ambient air quality and inform/recommend the regulatory authorities (statutory bodies) to initiate the actions if the concentrations exceeding the NAAQS.

\subsection{Emission estimates}

Estimation of emission rates from vehicle exhaust is the first step in the development of control strategies and a key component of ULAQM. It is directly proportional to pollutant concentrations at the receptor point. Further, qualitative and quantitative estimation of emissions from heterogeneous vehicle exhaust depends mainly on traffic volume, traffic fleet characteristics, vintage of vehicles, engine type, fuel adulteration and driver behaviour. A comprehensive, robust emission inventory seems to be the basis for selection of control strategies whose efficacy can be evaluated using an air quality model. In the present case study, emission rates have been estimated using a bottom-up approach (as defined in equations $1 \& 2$ ) for vehicles exhaust and re-suspension of road dust, respectively (Gulia et al., 2015b; ARAI, 2007; Amato et al., 2014; USEPA, 2011). The ARAI, 2007 published emission factors for Indian vehicles are developed based on average vehicle speed using Indian driving cycle, however, vehicle's speed is varying on real time traffic situation at different urban road conditions. Therefore, speed dependent emission factors need to be developed for Indian vehicles and basis emission inventory should be updated for accurate estimation of pollution load.

$\operatorname{ER}(i)=\sum(j) N(j, k) \times \operatorname{EF}(i, j, k) \times \operatorname{DF}(i, j, k) \times L$

where,

$\mathrm{ER}(\mathrm{i})=$ Emissions rate of pollutant ' $i$ '

$N(j, k)=$ Number of vehicles of a particular type 'j' and age of vehicle ' $k$ '

$\mathrm{EF}(\mathrm{i}, \mathrm{j}, \mathrm{k})=$ Emission factor for pollutant ' $\mathrm{i}$ ' in the vehicle type ' $\mathrm{j}$ ' and age ' $\mathrm{k}$ ' ( $\left.\mathrm{gm} \mathrm{km}^{-1}\right)$

$\operatorname{DF}(\mathrm{i}, \mathrm{j}, \mathrm{k})=$ Deterioration factor for pollutant ' $\mathrm{i}$ ' in the vehicle type ' $\mathrm{j}$ ' and age ' $\mathrm{k}$ '

$\mathrm{j}=$ Type of vehicle (2W-2S \& 4S, 3W-Petrol, Diesel \& CNG driven, 4W -Petrol, Diesel \& CNG

driven, Bus, Truck)

$\mathrm{L}=$ Road length $(\mathrm{m})$

$\mathrm{E}=\mathrm{k} \times(\mathrm{sL})^{0.91} \times(\mathrm{W})^{1.02}$

where,

$\mathrm{E}=$ particulate emission factor $(\mathrm{g} / \mathrm{VKT})$

$\mathrm{k}=$ particle size multiplier (g/VKT), default value of " $\mathrm{k}$ " for $\mathrm{PM}_{2.5}$ is $0.15 \mathrm{~g} / \mathrm{VKT}$

$\mathrm{sL}=$ road surface silt loading rate $\left(\mathrm{g} / \mathrm{m}^{2}\right)$ 
Prevailing meteorological conditions strongly influence the dispersion of air pollutant and play an important role in pollutant transport from source to receptor. The meteorological conditions depend on geographical location and local topography. Calm wind and significant emission sources are responsible for the occurrence of air pollution episodes. Therefore, monitoring and forecasting of meteorological parameters are important to predict pollutant concentrations during an episode. Air quality models need sufficient hourly average meteorological data, both temporally and spatially at the surface as well as upper air. Hourly average data of wind speed $(\mathrm{m} / \mathrm{s})$, wind direction (degree), cloud cover (tens), temperature $\left({ }^{0} \mathrm{C}\right)$, relative humidity $(\%)$, atmospheric pressure (mbar), precipitation $(\mathrm{cm})$, global solar radiation $\left(\mathrm{Wh} \mathrm{m}^{-2}\right)$ and ceiling height $(\mathrm{m})$ are required for air quality monitoring. In addition, the upper air sounding data includes atmospheric pressure (mbar), height $(\mathrm{m})$, temperature $\left({ }^{0} \mathrm{C}\right)$, relative humidity $(\%)$, wind direction (degree) and wind speed $(\mathrm{m} / \mathrm{s})$. Therefore, availability of these surface and upper air data for Indian conditions will be very useful for accurate predication of air pollutant concentrations.

\subsection{Air Quality Modelling}

Air quality modelling is the most important component of the ULAQM framework which predicts current as well as future air quality in order to enable informed policy decisions to be made. The ULAQM also predicts the occurrence of extreme pollutant concentrations during episodic condition. The ULAQM uses the hybrid model i.e. a combination of Gaussian dispersion and statistical distribution model to predict air pollutant concentrations and to evaluate the scenarios, especially during episodic conditions. The hybrid model predicts average as well as extreme pollutant concentrations satisfactorily (Gokhale and Khare, 2005; Sharma et al., 2013b; Gulia et al., 2017b). In the resent case study, the hybrid model has been developed by combining AERMOD (Gulia et al., 2017; Gulia et al., 2015b; Khare et al., 2012) and Lognormal/Log-logistic statistical distribution model to predict averages as well as extreme percentile ranges of pollutant concentrations at two selected urban locations (Gulia et al., 2017b). The developed hybrid model (AERMOD-Lognormal) predicts $\mathrm{NO}_{\mathrm{x}}$ and $\mathrm{PM}_{2.5}$ concentrations satisfactorily with index of agreement ' $d$ ' value of more than 0.95 during the winter season at selected locations in Delhi and Chennai cities, respectively. Further, the hybrid model has been used to simulate pollutant concentrations under different management/control option scenarios.

403

404

405

This is the first step of ULAQM framework to reduce pollutant emissions from source to improve strategies are evaluated for their efficacy, technical feasibility, implementation period, requirement 
of financial resources and social feasibility before adopting them directly. The control strategies need to be evaluated quantitatively in order to aseess their effect on pollution levels. Gulia et al. (2015a) have comprehensively reviewed these control strategies.

The framework formulates a robust Emergency Response Plan (ERP), which works under the umbrella of ULAQM to manage and prevent air pollution episodes. The ultimate objective of ERP is to reduce emissions during episodes and avoid public exposure to high pollutant concentrations. The ERP works in four steps. The first step is the forecast of pollutant concentrations using the hybrid model; second, the alert, when pollutant concentration exceeds the specified standard up to two times; third, the warning, which primarily indicates that air quality continues to deteriorate and additional control actions are needed; and fourth, the emergency, at which a substantial endangerment to human health is expected. Table 4 describes the criteria for declaration of an episode based on hourly average concentrations which may further improved based on health adversary. For 24-hour average concentrations, the criteria defined under recently notified Graded Response Action Plan (GRAP) by MoEF \& CC, can be used to forecast alert, warning and emergency conditions for AQI categories of moderate, poor, very poor and severe, respectively (MoEF \& CC, 2017).

Table 4: Criteria for declaration of an episode based on hourly average air pollutant concentrations

\section{ERP stage Criteria}

Forecast Possibility of a high air pollution potential in next few hours/days based on meteorological forecasting and air quality modelling result.

1-hr. average $\mathrm{NO}_{\mathrm{x}}: \geq 200 \mu \mathrm{g} / \mathrm{m}^{3}$

1-hr. average $\mathrm{PM}_{2.5}: \geq 80 \mu \mathrm{g} / \mathrm{m}^{3}$

$\begin{array}{ll}\text { Alert } & 1-\mathrm{hr} \text { average } \mathrm{NO}_{\mathrm{x}}: 201-400 \mu \mathrm{g} / \mathrm{m}^{3} \\ \text { Warning } & 1-\mathrm{hr} \text { average } \mathrm{PM}_{2.5}: 81-160 \mu \mathrm{g} / \mathrm{m}^{3} \\ & 1-\mathrm{hr} \text { average } \mathrm{NO}_{\mathrm{x}}: 401-600 \mu \mathrm{g} / \mathrm{m}^{3} \\ \text { Emergency } & 1-\mathrm{hr} \text { average } \mathrm{PM}_{2.5}: 161-240 \mu \mathrm{g} / \mathrm{m}^{3} \\ & 1-\mathrm{hr} \text { average } \mathrm{NO}_{\mathrm{x}}:>600 \mu \mathrm{g} / \mathrm{m}^{3} \\ & 1-\mathrm{hr} \text { average } \mathrm{PM}_{2.5}:>240 \mu \mathrm{g} / \mathrm{m}^{3}\end{array}$

In order to operate the ERP, it is proposed to establish an Emergency Response Centre (ERC), which may be an agency of existing pollution control authorities. The ERC may include a team of experts such as meteorologists, air quality modellers, transport planners, communication engineers, health experts and a coordinator. Further, it may serve as the interface between the policy makers and the pollution control authorities. The ERC operates in three different modes, i) routine surveillance (between air pollution episodes to check major activities); partial activation (during forecast and alert level) and full activation (during warning and emergency).

Once the episode is declared, emergency response strategies are implemented to reduce the pollutant emission rates. The emergency response strategies are integrated, pre-planned groups of 
emission reduction actions that are available to the ERC for episode avoidance. The mitigation strategies should be selected based on their relative contribution to pollution, potential to reduce emission rates, the time required for emission reduction and socio-economic impacts. The ERC must also have an effective public information program.

\subsection{Public participation}

The public plays an influential role in formulating ULAQM as the management activities impact them by influencing their activities and expectations. Public participation is not only limited to sharing timely information regarding air quality (e.g. good or bad), but also involves them actively throughout the formulation of a management plan, i.e. from goal setting to policy implementation. A well-planned information dissemination system serviced by efficient communication is essential for management of an air pollution episode. The effectiveness of the ERP depends upon rapid and accurate transmission of information from the surveillance equipment to the ERC and related abatement instructions from the ERC to the emitters. This process of communication is reversible. Most of the information transmits to the public through the news media in a standard format: information regarding the duration and intensity of the episode, health precautions and other aspects of episode disseminates through a variety of techniques (SI Table S2). The information system operates in three phases, i.e., before the episode, during an episode and following an episode. ERC prepares an effective episode information plan before the episode and it will be enacted during the episode for activation; after an episode, it serves to audit the activities. All the information during the episode is to be reported in a proper format for legal purposes and to provide more effective actions to control future episodes.

\subsection{Policy proposal and its implementation}

Once the control strategies are evaluated, all the actions plan/responses are put together to make a policy for that particular NAA. Policymaking must be an agreed procedure by which air quality goals are progressively achieved across a specified period, i.e., long-term as well as short-term. The long timescale means that the land use and transport plans for a local authority can be integrated with the ULAQM and the projected outcomes of the land use and transport plans tested within its framework. The developed policy needs an implementation plan for these site-specific ULAQM. The public must be consulted throughout policy development and implementation through awareness programs and proper communication systems (SI Table S2). Continuous capacity building and training programs may be organised to identify needs and knowledge gaps in ULAQM.

\subsection{Evaluation}

It is also an important component of any management practice to fill the gaps in the system. It is necessary to check the working of a management plan to ensure continued consistency with other policies. The framework acts as a decision support system (DSS) for policy makers and regulators 
477 for effective and efficient urban air quality management at NAAs. It provides scientifically sound 478 information on emission sources, meteorological conditions, predicted pollutant concentrations, 479 frequency of violations of standards and control strategies (Elbir et al., 1997).

\subsection{Evaluation of ULAQM framework}

482 The developed ULAQM framework has been evaluated for two selected NAAs in Delhi (NAA1) 483 and Chennai (NAA2) cities during the winter period for $\mathrm{NO}_{\mathrm{x}}$ and $\mathrm{PM}_{2.5}$, respectively.

486 The ITO intersection is one of the busiest traffic intersections in Delhi (Gulia et al., 2017b; Mohan 487 and Kandya, 2007), and surrounded by densely populated commercial and residential areas. Four 488 major roads meet at this intersection, namely, Road 1: Dean Dayal Upadhaya Marg (DDU, towards 489 West); Road 2 \& 4: Bahadur Shah Zafar Marg (BSZ, towards North and South, respectively) and 490 Road 3: Inderaprastha Marg (IP, towards East). The ambient monitoring station is located at a 491 distance of 12 metres from Road 2 (Figure 2). Approximately, 0.23 million vehicles per day cross 492 this intersection. Past studies (Goyal et al., 2010; Pant et al., 2015; Sindhwani et al., 2015) have 493 reported frequent violations of NAAQS, particularly during winter periods and it has been reported 494 as one of the urban hotspots for air pollution in Delhi city. Historical $\mathrm{NO}_{\mathrm{x}}$ concentration monitoring 495 data is taken from the CPCB monitoring station at NAA1 for 2009-2010 and the traffic data from 496 the Central Road Research Institute for 2010. These data have been used to estimate the $\mathrm{NO}_{\mathrm{x}}$ 497 emission rate. The site features are obtained from a field survey. The details of input parameters 498 for the hybrid model development are described in SI Table S3. 


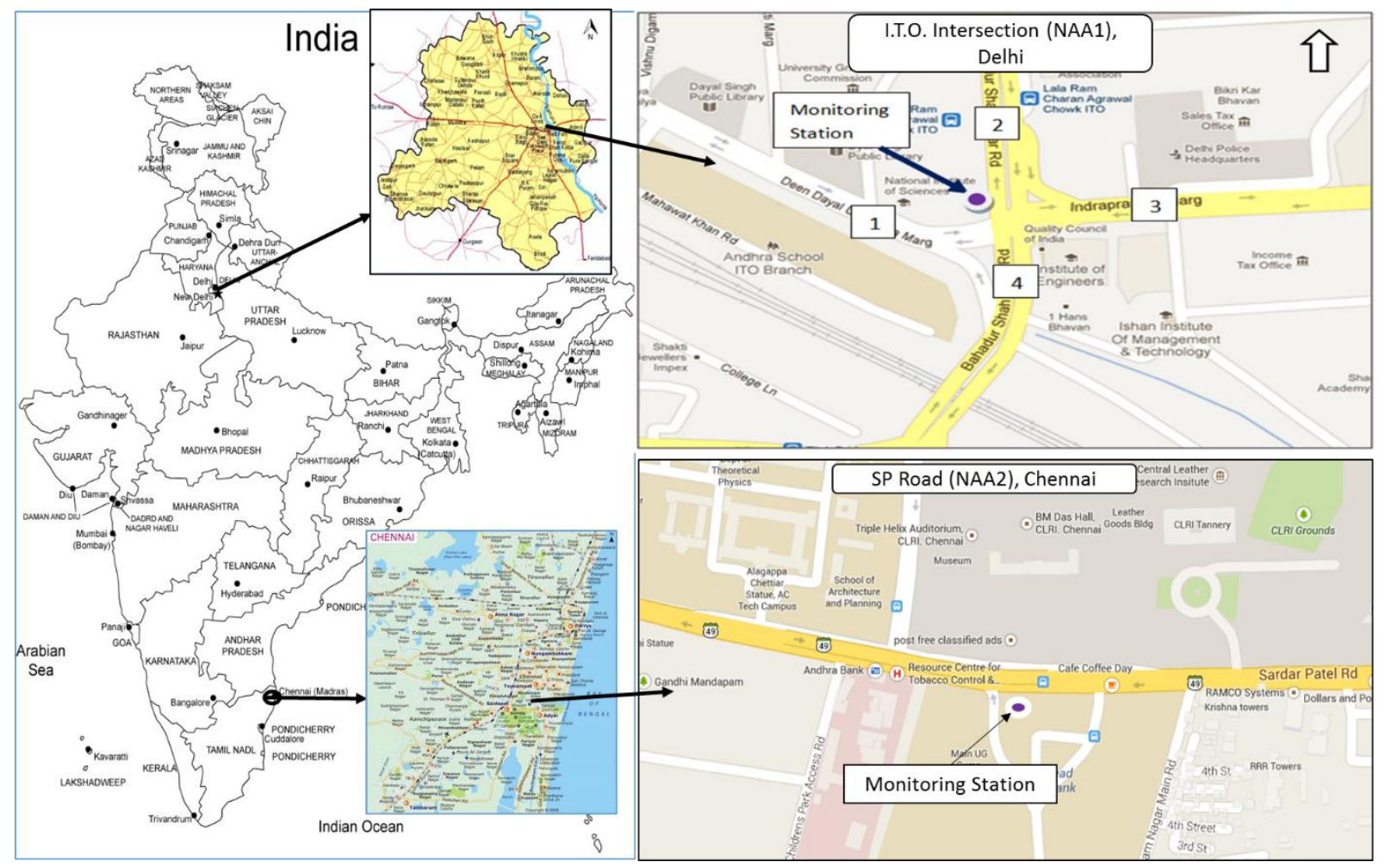

500 (Gulia et al., 2017a)

The hybrid model i.e. AERMOD-Lognormal, performs satisfactorily in predicting $\mathrm{NO}_{\mathrm{x}}$ concentration at NAA1 having an index of agreement (d) value greater than 0.95 (Gulia et al. 2017b). The AERMOD-Lognormal hybrid model has been applied to evaluate the impact of traffic management strategies to reduce $\mathrm{NO}_{\mathrm{x}}$ concentration levels at NAA1 (Table 5).

Scenario \#1: This scenario suggests restriction of LCVs and HCVs within the NAA1 during peak traffic hours i.e. 09:00 - 11:00 and 18:00 - 21:00. Additionally, an odd-even car scheme applied to all private and commercial cars which may reduce about $50 \%$ of the total $4 \mathrm{~W}$ at NAA1. The entry of inter-state buses through NAA1 is also not allowed. It is assumed that $50 \%$ of the total city buses are plying during peak hours.

Scenario \#2: This scenario suggests restriction on the entry of LCVs, HCVs and buses within the NAA1 during peak traffic hours i.e. 09:00 - 11:00 and 18:00 - 21:00.

Scenario \#3: This scenario suggests enforcement of congestion charges on vehicles passing through NAA1. It is assumed that this traffic strategy will reduce $50 \%$ of total $2 \mathrm{~W}, 3 \mathrm{~W}$ and $4 \mathrm{~W}$ at NAA1. To compensate this reduction in traffic, the volume of buses are estimated and assumed to ply through NAA1. Therefore, buses volume is increased by 6\%, i.e. 499 buses. The HCVs are not 
Table 5: Traffic management strategies at NAA1

\begin{tabular}{lcccc}
\hline Types of & \multicolumn{4}{c}{ Traffic volume (\% age) } \\
Vehicle & Base case & Scenario & Scenario 2 & Scenario 3 \\
\hline $\mathbf{2 W}$ & 37 & 37 & 37 & 18.5 \\
\hline $\mathbf{3 W}$ & 18 & 18 & 18 & 9 \\
\hline $\mathbf{4 W}$ & 40 & 20 & 40 & 20 \\
\hline LCV & 2 & $0^{*}$ & $0^{*}$ & $0 *$ \\
\hline HCV & 2 & $0^{*}$ & $0^{*}$ & 0 \\
\hline Bus & 1 & 0.5 & $0^{*}$ & 1.06 \\
\hline Total & 100 & 71.5 & 95 & 48.56 \\
\hline
\end{tabular}

* During peak traffic hours only

522

523

524

525

526

527

528

529

530

531

532

533
Table 6 describes results of these three scenarios in the reduction of $\mathrm{NO}_{\mathrm{x}}$ concentrations at NAA1. It is observed that traffic management strategies in scenarios 1 and 3 have efficiently reduced $\mathrm{NO}_{\mathrm{x}}$ concentration in line with WHO guidelines.

Table 6: Scenario evaluation at NAA1

\begin{tabular}{|c|c|c|c|}
\hline Sr. & Item & \multicolumn{2}{|c|}{ Descriptions } \\
\hline 1 & Hybrid model* & \multicolumn{2}{|c|}{ AERMOD-Lognormal } \\
\hline 2 & $\begin{array}{l}\text { Parameter } \\
\text { estimation }\end{array}$ & Location $(\mu)$ & Scale $(\sigma)$ \\
\hline 2.1 & Base case & 4.201 & 0.858 \\
\hline 2.2 & Scenario1 & 3.459 & 0.6796 \\
\hline 2.3 & Scenario2 & 4.124 & 0.8664 \\
\hline 2.4 & Scenario 3 & 3.465 & 0.5624 \\
\hline 3 & $\begin{array}{l}\text { Hybrid model } \\
\text { output }\end{array}$ & $\begin{array}{l}\text { Probability } \\
\qquad(\mathrm{x} \leq 200 \\
\left.\mu \mathrm{g} / \mathrm{m}^{3}\right)(\%)\end{array}$ & $\begin{array}{c}\text { WHO_AQG criteria being } \\
\text { met or not (Yes } / \mathrm{No})\end{array}$ \\
\hline 3.1 & Base case & 89.95 & NO \\
\hline 3.2 & Scenario1 & 99.66 & Yes \\
\hline 3.3 & Scenario2 & 91.24 & NO \\
\hline 3.4 & Scenario 3 & 99.94 & Yes \\
\hline
\end{tabular}

(*Gulia et al. 2017b)

\subsection{At SP road, Chennai (NAA2): $\mathrm{PM}_{2.5}$ control}

The SP road is one of the busiest road corridors in Chennai city and surrounded by densely populated institutional and residential areas (Figure 2). The traffic density on NAA2 is approximately 0.17 and 0.14 million vehicles per day during weekdays and weekends, respectively. Frequent violations of NAAQS have been observed (Srimuruganandam and 
Nagendra, 2011). The monitoring station is located on the kerbside of SP road (in the southbound direction from SP road) near IIT Madras main entrance gate. Historical $\mathrm{PM}_{2.5}$ concentration data (2008-2009) has been collected by the air quality laboratory of IIT Madras. The traffic volume and fleet characteristics data of the SP road for the study period and the site features were collected from field surveys.

The hybrid model, AERMOD-Lognormal, performs satisfactorily in predicting $\mathrm{PM}_{2.5}$ concentrations at NAA2 having the index of agreement (d) value greater than 0.90 (Gulia et al. 2017b). The AERMOD-Lognormal hybrid model has been applied to evaluate the impact of traffic management strategies to reduce $\mathrm{PM}_{2.5}$ concentration levels at NAA2. The traffic management strategies are described in Table 7.

Scenario \#1: In this scenario, only $80 \%$ of $2 \mathrm{~W}, 3 \mathrm{~W}, 4 \mathrm{~W}$ and LCVs are allowed to enter through NAA2.

Scenario \#2: This scenario suggests that only $60 \%$ of traffic (except buses) is allowed to enter through NAA2. To compensate this reduction, the volume of buses which is allowed to ply through NAA2 is increased by $20 \%$.

Scenario \#3: In this scenario, only $50 \%$ of $2 \mathrm{~W}, 3 \mathrm{~W}, 4 \mathrm{~W}$ and LCVs are allowed to enter through NAA2. Additionally, buses are increased by $6 \%$. HCVs are not allowed to enter NAA2 during peak traffic hours.

Table 7 describes the above scenarios in terms of data which are used as input in application of the ULAQM. It is observed that traffic management strategies as selected in all three scenarios are not sufficient in reducing the $\mathrm{PM}_{2.5}$ levels up to specified standards. This clearly indicates that more stringent control strategies are needed to be implemented at NAA2.

Table 7: Traffic management strategies at NAA2

\begin{tabular}{lcccc}
\hline Types of & \multicolumn{4}{c}{ Traffic fleet (percentage) } \\
\cline { 2 - 5 } Vehicle & Base case & Scenario1 & Scenario2 & Scenario 3 \\
\hline $\mathbf{2 W}$ & 50 & 40 & 30 & 25 \\
\hline $\mathbf{3 W}$ & 6 & 4.8 & 3.6 & 3 \\
\hline $\mathbf{4 W}$ & 35 & 28 & 21 & 17.5 \\
\hline $\mathbf{L C V}$ & 4 & 2 & 2.4 & 4 \\
\hline HCV & 2 & 1 & 1.2 & $0 *$ \\
\hline Bus & 3 & 3 & 3.6 & 3.18 \\
\hline Total & 100 & 78.8 & 61.8 & 52.68
\end{tabular}

*During peak traffic hour

Table 8 describes the results of the analysis of the ULAQM incorporating the above scenarios.

Table 8: Scenario evaluation at NAA2

\begin{tabular}{llc}
\hline Sr. no. & Item & Descriptions \\
\hline $\mathbf{1}$ & Hybrid model $*$ & AERMOD-Lognormal \\
\hline
\end{tabular}




\begin{tabular}{llrcc}
\hline $\mathbf{2}$ & Parameter estimation & \multicolumn{2}{c}{ Location $(\mu)$} & Scale $(\sigma)$ \\
\hline $\mathbf{2 . 1}$ & Base case & \multicolumn{2}{c}{4.093} & 0.6742 \\
\hline $\mathbf{2 . 2}$ & Scenario1 & \multicolumn{2}{c}{3.943} & 0.6336 \\
\hline $\mathbf{2 . 3}$ & Scenario2 & \multicolumn{2}{c}{3.909} & 0.593 \\
\hline $\mathbf{2 . 4}$ & Scenario3 & \multicolumn{2}{c}{3.725} & 0.5107 \\
\hline $\mathbf{3}$ & Hybrid model output & $\begin{array}{c}\text { Probability } \\
\left(\mathrm{x} \leq 80 \mu \mathrm{g} / \mathrm{m}^{3}\right) \\
(\%)\end{array}$ & $\begin{array}{c}\text { Probability } \\
\left(\mathrm{x} \geq 80 \mu \mathrm{g} / \mathrm{m}^{3}\right) \\
(\%)\end{array}$ & $\begin{array}{c}\text { Standard met } \text { not } \\
(\text { Yes } / \mathrm{No})\end{array}$ \\
\hline $\mathbf{3 . 1}$ & Base case & 66.59 & 33.41 & NO \\
\hline $\mathbf{3 . 2}$ & Scenario1 & 75.58 & 24.42 & NO \\
\hline $\mathbf{3 . 3}$ & Scenario2 & 78.75 & 21.25 & NO \\
\hline $\mathbf{3 . 4}$ & Scenario 3 & 90.09 & 9.91 & NO \\
\hline
\end{tabular}

\section{(*Gulia et al., 2017b)}

This ULAQM framework has introduced the concept of urban air quality management at local level for Indian mega cities having different climatic conditions and heteorogenity in emission sources. The case study results have also described the efficiency of ULAQM in reduction of pollutant concentrations at selected NAAs in Indian cities. Following DEFRA, 2017 which described the implementation of best management practices under LAQM guidelines to improve air quality in terms of $\mathrm{NO}_{2}$ and $\mathrm{PM}_{10}$ in the designated AQMAs in the UK, the present ULAQM framework may assist policy makers to develop the ULAQM guidelines for Indian cities.

\subsection{Conclusion}

Ad hoc air quality control actions are not sufficient to prevent air pollution episodes in Indian cities. Additionally, poor communication among policy makers, air quality experts, urban local bodies (who ensure implementation of policy) and the public (who are affected by the policies) make air quality management more challenging. In the absence of integrated urban air quality management policy and increasing concerns of the general public, an ULAQM framework has been formulated and evaluated for selected NAAs in Delhi and Chennai cities of India. The role and importance of each key component of the ULAQM have been discussed in detail along with their inter-connectivity and flow of information.

The developed ULAQM framework has been applied at NAA1 and NAA2 in Delhi and Chennai cities, respectively to evaluate it with respect to different scenarios for two criteria pollutants i.e. $\mathrm{NO}_{\mathrm{x}}$ and $\mathrm{PM}_{2.5}$. The results of the case study examples clearly indicate that ULAQM framework provides comparative ambient air quality management/control options based on scenario analysis that can be appropriately chosen and implemented by the concerned air pollution control authorities to keep the selected air pollutant concentration levels within the specified standards. Further, the ULAQM framework may also assist policy makers to develop the ULAQM guidelines for other Indian cities to improve ambient air quality in designated NAAs. 
- Amann M, Purohit P, Bhanarkar AD, Bertok I, Borken-Kleefeld J, Cofala J, Majumdar D. Managing future air quality in megacities: A case study for Delhi. Atmos Environ, 2017; 161: 99-111.

- Amato F, Cassee FR, Denier van der Gon HA, Gehrig R, Gustafsson M, Hafner W, Querol $\mathrm{X}$, Urban air quality: The challenge of traffic non-exhaust emissions. J Hazard Mater, 2014; http://dxdoiorg/doi:101016/jjhazmat201404053.

- ARAI. Emission factor development for Indian vehicles. Project report no AEF/200607/IOCL/Emission Factor Project, Automotive Research Association of India, Pune, India; 2017.

- Badami MG. Transport and urban air pollution in India. Environ Manage, 2005; 36: 195-204.

- Baeza CC, Pardo CS. Sustainable passenger road transport scenarios to reduce fuel consumption air pollutants and GHG (greenhouse gas) emissions in the Mexico City. Metropolitan Area Energy, 2014; 66: 624-634.

- Beattie CI, Longhurst JWS, Woodfield NK. Air Quality Action Plans: early indicators of urban local authority practice in England. Environ Sci Policy, 2002; 5: 463-470.

- Cakmak S, Hebbern C, Cakmak JD, Vanos J. The modifying effect of socioeconomic status on the relationship between traffic air pollution and respiratory health in elementary school children. J of Environ Manage, 2014; 177: 1-8.

- Census 2011, Delhi and Chennai City Population. Available at http://www.census2011.co.in/census/state/delhi.html; http://wwwcensus2011coin/census/city/463-chennaihtml

- Chelani AB. Study of extreme $\mathrm{CO} \mathrm{NO}_{2}$ and $\mathrm{O}_{3}$ concentrations at a traffic site in Delhi: Statistical persistence analysis and source identification. Aerosol Air Qual Res, 2013; 13: 377384.

- Cohan DS, Chen R. Modelled and observed fine particulate matter reductions from state attainment demonstrations. J Air Waste Manage Assoc, 2014; 64: 995-1002.

- CPCB. Air quality trends and action plan for control of air pollution from seventeen studies. The Central Pollution Control Board, Ministry of Environment and Forest, New Delhi, India, 2009, NAAQMS/29/2006-07.

- CPCB. Air quality monitoring emission inventory and source apportionment study for Indian cities. National Summary Report, The Central Pollution Control Board, Ministry of Environment and Forest, India, 2010a.

- CPCB. Status of the vehicular pollution control programme in India. The Central Pollution Control Board, Ministry of Environment and Forest, India, Probes/ 136, 2010b.

- CPCB. Guidelines for the Measurement of Ambient Air Pollutants VOLUME-II. Central Pollution Control Board, Ministry of Environment Forest and Climate Change. Available at http://cpcbnicin/NAAQSManualVolumeIIpdf, 2011. 
- CPCB. Annual Report. Central Pollution Control Board, Govt. of India, New Delhi Available at http://cpcbnicin/upload/AnnualReports/AnnualReport_55_Annual_Report_2014-15pdf, 2015.

- DEAT. Manual for air quality management planning. Department of Environmental Affairs and Tourism, Republic of South Africa, 2008.

- DEFRA. Part IV of the Environment Act 1995, Local Air Quality Management Policy Guidance (PG16), Department for Environment Food \& Rural Affairs, London UK. Available at https://laqmdefragovuk/documents/LAQM-PG16-April-16-v1pdf, 2016.

- DEFRA. Good practice examples of the implementation of action plan measures. Department of Environment Food and Rural Affairs, Available on <https://laqmdefragovuk/actionplanning/case-studieshtml> Accessed on 06 July, 2017.

- DEQ Idaho. Rule for the control of air pollution in Idaho (IDAPA 580101). Department of Environment Quality Idaho, USA, 2001.

- Dhyani R, Sharma N, Maity AK. Prediction of $\mathrm{PM}_{2.5}$ along urban highway corridor under mixed traffic conditions using CALINE4 model. J Environ Manage, 2017; 198: 24-32.

- EEA. Laying the foundations for greener transport. Transport indicators tracking progress towards environmental targets in Europe. Technical Report No.7/2011 European Environment Agency Copenhagen, 2011.

- EEA. Success stories within the road transport sector on reducing greenhouse gas emission and producing ancillary benefits. Technical report No 2/2008, European Environment Agency Copenhagen, 2008.

- Elbir T, Muezzinoglu Fedra K. An application of environmental decision support systems used for air quality management. Environ Res, 1997; 7-8: 648-653.

- Fu L, Hunt K, Myrick B, Aklilu Y. One-hour equivalent of a 24-hour average particulate matter standard and its potential application in the index of the quality of the air (IQUA). Presented at the Air and Waste Management Association (AWMA) Conference Banff Alberta, April 10-12, Available at https://extranetgovabca/env/infocentre/info/library/6672pdf, 2000.

- GoD, Goverment of Delhi Chapter 12 Transport Economic Survey of Delhi 2014-15. Available http://delhigovin/wps/wcm/connect/DoIT_Planning/planning/economic+survey+of+dehli/ec onomic+survey+of+delhi+2014+2015 (accessed 27.02. 2016).

- Gokhale S, Khare M. A hybrid model for predicting carbon monoxide from vehicular exhausts in urban environments. Atmos Environ, 39; 4025-4040.

- Gokhale S, Khare M. A theoretical framework for the episodic-urban air quality management plan (e-UAQMP). Atmos Environ, 2014, 41: 7887-7894.

- Gulia S, Nagendra SMS, Khare M, Khanna I. Urban air quality management - A review. Atmos Pollut Res, 2015a; 6: 286-304. 
- Gulia S., Nagendra SMS, Khare M. Comparative evaluation of air quality dispersion models for $\mathrm{PM}_{2.5}$ at Air Quality Control Regions in Indian and UK Cities. MAPAN, 2015b; 30: 249260

- Gulia S, Nagendra SS, Khare M. Extreme events of reactive ambient air pollutants and their distribution pattern at urban hotspots. Aerosol Air Qual Res, 2017a; 17: 394-405.

- Gulia S, Nagendra SMS, Khare M. A system based approach to develop hybrid model predicting extreme urban $\mathrm{NO}_{\mathrm{x}}$ and $\mathrm{PM}_{2.5}$ concentrations. Trans Res Part-D: Trans and Environ, 2017b; 56C; 141-154.

- Gupta I, Kumar R. Trends of particulate matter in four cities in India. Atmos Environ, 2006; 40: 2552-2566,

- Gupta I, Salunkhe A, Kumar R. Modelling 10-year trends of PM $_{10}$ and related toxic heavy metal concentrations in four cities in India. J Hazard Mater, 2010; 179: 1084-1095.

- Gupta NS. Chennai tops in vehicle density. The Times of India, Available from: http://timesofindiaindiatimescom/business/india-business/Chennai-tops-in-vehicledensity/articleshow/47169619cms (accessed 07062015), 2015.

- Gurjar BR, Ravindra K, Nagpure AS. Air pollution trends over Indian megacities and their local-to-global implications. Atmos Environ, 2016; 142: 475-495.

- Gurjar BR, Butler TM, Lawrence MG, Lelieveld J. Evaluation of emissions and air quality in megacities. Atmos Environ, 2008; 42: 1593-1606.

- Guttikunda SK, Goel R, Pant P. Nature of air pollution emission sources and management in the Indian cities. Atmos Environ, 2014; 95: 501-510.

- Guttikunda SK, Goel R. Health impacts of particulate pollution in a megacity-Delhi India. Environ Develop, 2013; 6: 8-20.

- Hasheminassab S, Daher N, Ostro BD, Sioutas C. Long-term source apportionment of ambient fine particulate matter $\left(\mathrm{PM}_{2.5}\right)$ in the Los Angeles Basin: A focus on emissions reduction from vehicular sources. Environ Pollut, 2014; 193: 54-64.

- Hsu A, Zomer A. An Interactive Air-Pollution Map Available on http://wwwepiyaleedu/themetric/interactive-air-pollution-map (accessed 02 March 2016.), 2014.

- IITM. System of Air Quality and Weather Forecasting and Research (SAFAR). Indian Institute of Tropical Meteorology Pune. Ministry of Earth Science, Govt. of India. Available from http://safartropmetresin/indexphp (accessed on 18 May), 2017.

- Jayanthi V, Krishnamoorthy R. Key airborne pollutants - impact on human health in Manali Chennai. Current Sci, 2006; 90: 405-413.

- Kanlindkar M. Air pollution at a hotspot location in Delhi: Detecting trends seasonal cycles and oscillations Atmos Environ, 2007; 41: 5934-5947.

- Kesavachandran CN, Kamal R, Bihari V, Pathak MK, Singh A. Particulate matter in ambient air and its association with alterations in lung functions and respiratory health problems among outdoor exercisers in National Capital Region India. Atmos Pollut Res, 2015; 6: 618-625. 
- Khare M, Nagendra SMS, Gulia S. Performance evaluation of air quality dispersion models at urban intersection of an Indian city: a case study of Delhi city. Proceeding of 20th WIT international conference on Air Pollution at La Coruna, Spain, 2012; 157: 249-259.

- Kumar P, Gulia S, Harrison RM, Khare M. The influence of odd-even car trial on fine and coarse particles in Delhi. Environ Pollut, 2017; 225: 20-30.

- Kumar P, Gurjar BR, Nagpure A, Harrison RM. Preliminary estimates of nanoparticle number emissions from road vehicles in megacity Delhi and associated health impacts Environ Sci Technol, 2011; 45: 5514-5521.

- Kumar P, Khare M, Harrison RM, Bloss WJ, Lewis AC, Coe H, Morawska L. New directions: Air pollution challenges for developing megacities like Delhi. Atmos Environ, 2015a; 122: 657-661.

- Kumar P, Morawska L, Martani C, Biskos G, Neophytou M, Di Sabatino S, Britter R. The rise of low-cost sensing for managing air pollution in cities. Environ Intern, 2015b; 75: 199205.

- Kumar P, Saroj DP. Water-energy-pollution nexus for growing cities. Urban Clim, 2014; 10 : 846-853.

- Kura B, Verma S, Ajdari E, Iyer A. Growing public health concerns from poor urban air quality: strategies for sustainable urban living. Comput Water Energy Environ Engg 2013; 2: $1-9$.

- Lelieveld J, Evans JS, Fnais M, Giannadaki D, Pozzer A. The contribution of outdoor air pollution sources to premature mortality on a global scale. Nature, 2015; 525: 367-371

- Li Y, Chang M, Ding S, Wang S, Ni D, Hu H. Monitoring and source apportionment of trace elements in $\mathrm{PM}_{2.5}$ : Implications for local air quality management. J Environ Manage, 2017; 196: 16-25.

- Longhurst JWS, Lindley SJ, Watson AFR, Conlan DE. The introduction of local air quality management in the United Kingdom: A review and theoretical framework. Atmos Environ, 1996; 30: 3975-3985.

- Maji KJ, Dikshit AK, Deshpande A. Disability-adjusted life years and economic cost assessment of the health effects related to $\mathrm{PM}_{2.5}$ and $\mathrm{PM}_{10}$ pollution in Mumbai and Delhi in India from 1991 to 2015. Environ Sc and Pollut Res, 2017; 24: 4709-4730.

- Mandal P, Saud T, Sarkar R, Mandal A, Sharma SK, Mandal TK, Bassin JK. High seasonal variation of atmospheric $\mathrm{C}$ and particle concentrations in Delhi India. Environ Chem Lett, 2014; 12: 225-230.

- Marlier ME, Jina AS, Kinney PL, DeFries RS. Extreme air pollution in global megacities. Current Climate Change Reports, 2016; 2: 15-27.

- MoEF\&CC. Graded Response Action Plan to combat air pollution in Delhi and National Capital Region Ministry of Environment Forest and Climate Change Govt of India, 2017.

- MoEF\&CC, National ambient air quality standards Ministry of Environment Forest and Climate Change New Delhi India Notification number: SO3067 (E) pages 4, 2009. 
- Mohan M, Kandya A. An analysis of the annual and seasonal trends of air quality index of Delhi. J Environ Monit Assess, 2007; 131: 267-277.

- Molina LT, Kolb CE, Foy B, de Lamb BK, Brune WH, Jimenez JL, Molina MJ. Air quality in North America's most populous city - overview of MCMA-2003 Campaign. J Atmos Chem Phys, 2007; 7: 2447-2473.

- MoPNG. Urban road traffic and air pollution study (URTRAP) (2002), Sponsored by Ministry of Petroleum and Natural Gases (MoPNG) Govt. of India on behalf of Mashelkar Committee, 2003.

- MoPNG. All India Study on Sectoral Demand of Diesel \& Petrol Report Petroleum Planning and Analysis Cell, Sponsored by Ministry of Petroleum and Natural Gases (MoPNG) Govt of India, 2013.

- MoRTH. Ministry of Road Transport and Highways Notification regarding amendment in Central Motor Vehicles Rule 1988 for shift of fuel from BS-IV to BS VI from $1^{\text {st }}$ April 2020 Available http://wwwindiaenvironmentportalorgin/files/file/Mass\%20Emission\%20Norms\%20for\%20 BS-VI pdf, 2016.

- MoRTH. Annual Report-2016-17. Ministry of Road Transport and Highways, Govt. of India, 2017.

- Moussiopoulos N, Douros I, Tsegas G, Kleanthous S, Chourdakis E. An air quality management system for Cyprus Global NEST Journal, 2010; 12: 92-98.

- Madala S, Prasad KH, Srinivas CV, Satyanarayana ANV. Air quality simulation of NO X over the tropical coastal city Chennai in southern India with FLEXPART-WRF. Atmos Environ, 2016; 128: 65-81.

- Naiker Y, Diab RD, Zunckel M, Hayes ET. Introduction of local Air Quality Management in South Africa: overview and challenges. Environ Sci Policy, 2012; 17: 62-71.

- NCR. National Capital Region Regional Plan Draft Revised Regional Plan 2021. National Capital Region (Approved in 33rd Meeting of the NCR Planning Board held on 1st July 2013) July 2013, National Capital Region Planning Board Ministry of Urban Development, Goverment of India, 2013.

- NILU. Air Quality Management Plan for e-Thekwini Municipality Kwa-Zulu Natal South Africa. Produced by eThekwini Health and Norwegian Institute for Air Research, 2007.

- NRC. National Research Council report on Air quality management in the United States ISBN: 978-0-309-08932-6, 2004.

- NSW. Government Current air quality in New South Wales Australia -a technical paper supporting the Clean Air Forum, DECCW, 728, 2010.

- Perrino C, Tiwari S, Catrambone M. Dalla Torre S, Rantica E, Canepari S. Chemical characterization of atmospheric PM in Delhi, India, during different periods of the year including Diwali festival. Atmos Pollut Res, 2011; 2; 418-427. 
- Pant P, Shukla A, Kohl SD, Chow JC, Watson JG, Harrison RM.Characterization of ambient $\mathrm{PM}_{2.5}$ at a pollution hotspot in New Delhi India and inference of sources. Atmos Environ, 2015; 109: 178-189.

- Parrish DD, Singh HB, Molina L, Madronich S. Air quality progress in North American megacities: A review. Atmos Environ, 2011; 45: 7015-7025

- Ramachandra TV, Shwetmala. Emissions from India's transport sector: State wise synthesis. Atmos Environ, 2009; 43: 5510-5517.

- Sharma P, Sharma P, Jain S, Kumar P. An integrated statistical approach for evaluating the exceedence of criteria pollutants in the ambient air of megacity Delhi. Atmos Environ, 2013a; 70: 7-17.

- Sharma S, Sharma P, Khare M. Hybrid modelling approach for effective simulation of reactive pollutants like Ozone. Atmos Environ, 2013b; 80: 408-414.

- Singh AK, Gupta HK, Gupta K, Singh P, Gupta VB, Sharma RC. A comparative study of air pollution in Indian cities. Bullet Environ Conta Toxico, 2007; 78: 411-416.

- Sivaramasundaram K, Muthusubramanian P. A preliminary assessment of $\mathrm{PM}_{10}$ and TSP concentrations in Tuticorin India. Air Qual Atmos Health, 2010; 3: 95-102.

- Sivertson B. Air quality management planning for urban Areas around the world. Proceeding in NACA/IUAPPA Conference South Africa 1 - 3 October, 2008.

- Soret A, Jimenez-Guerrero P, Andres D, Cardenas F, Rueda S, Baldasano JM. Estimation of future emission scenarios for analysing the impact of traffic mobility on a large Mediterranean conurbation in the Barcelona Metropolitan Area (Spain). Atmos Pollut Res, 2013; 4: 22-32.

- Srimuruganandam B, Nagendra SMS. Characteristics of particulate matter and heterogeneous traffic in the urban area of India. Atmos Environ, 2011; 45: 3091-3102.

- Srimuruganandam B, Nagendra SMS. Source characterization of $\mathrm{PM}_{10}$ and $\mathrm{PM}_{2.5}$ mass using a chemical mass balance model at urban roadside. Sci of the Total Environ, 2012; 433: 8-19.

- Steinar L, Grqnskei KE, Hannegraaf MC, Jansen H, Kuik OJ, Oosterhuis FH, Olsthoorn XA, Jitendra JS, Tanvi N, Carter JB. Urban air quality management strategy in Asia - a Guidebook. The World Bank Press, 1997.

- Tiwari S, Bisht DS, Srivastava AK, Pipal AS, Taneja A, Srivastava MK, Attri SD. Variability in atmospheric particulates and meteorological effects on their mass concentrations over Delhi India. Atmos Res, 2014; 145: 45-56.

- Tiwari S, Chate DM, Pragya P, Ali K, Bisht DS. Variations in mass of the $\mathrm{PM}_{10}, \mathrm{PM}_{2.5}$ and $\mathrm{PM}_{1}$ during the monsoon and the winter at New Delhi. Aerosol and Air Qual Res, 2012; 12 : 20-29.

- USEPA. Compilation of air pollutant Emission Factors: miscellaneous sources: paved roads final section. US Environment Protection Agency AP 42 Fifth Ed, 2011.

- Wang H, Fu L, Zhou L, Du X, Ge W. Trends in vehicular emissions in China's mega cities from 1995 to 2005. Environ Pollut, 2010, 158: 394-400. 
816

817

818

- WHO. WHO Air Quality guidelines for particulate matter ozone nitrogen dioxide and sulphur dioxide Global update 2005. World Health Organization Geneva, 2005. 